\title{
Impact of Remittances on Consumption and Investment (Case Study of Tehsil Sargodha, Punjab, Pakistan)
}

\author{
Waqas Javaid* \\ Umea University Sweden, Germany \\ *Corresponding author: waqasjavaid9@yahoo.com
}

\begin{abstract}
This paper investigates the impact of remittances (internal and external) on consumption and investment behavior of the households. The literature on the impact of remittances on consumption and investment, however, is exceptional, in context of Pakistan. To examine the impact of remittances, primary data was collected from the field survey of four main villages of Tehsil Sargodha (Punjab) Pakistan. The methodology used for the study, is regression model. The results show that remittances has positively related with consumption and investment. Furthermore, the study found the household behavior regarding consumption and investment is positive.
\end{abstract}

Keywords: worker remittance, foreign direct investment, official development assistance, growth, Pakistan

Cite This Article: Waqas Javaid, "Impact of Remittances on Consumption and Investment (Case Study of Tehsil Sargodha, Punjab, Pakistan)." Journal of Finance and Economics, vol. 5, no. 4 (2017): 156-163. doi: 10.12691/jfe-5-4-1.

\section{Introduction}

The aim of this study is to investigate what role remittances together with socio-economic variables play in consumption (durable and non-durable) and investment behaviors of the household at micro level.

Remittances have been considered as backbone for the economic growth of the developing countries in different periods of their history; due to dependence on remittances they are able to create better economic conditions. Most of the European countries in the past were dependent on the inflow of remittances from abroad in 19th and 20th century, which is why the economic level of these countries is higher today [23]. As the economy (GDP) of developed countries grows, more individuals in less developed countries have decided to migrate to these developed destinations of the world. As more emigration occurred so has the level of remittances increased? The level of remittances is higher than in any time in history and will increase to contribute more during depressed economic conditions and crises. The role of remittance at the macro level has seen positive effects on development improvement, maintaining economic stability, security from economic shocks and decrease in the level of poverty [23].

During 2006, World Bank estimated the total remittances growth per year at nearly 30\% and the remittance level was estimated to US\$250 billion [27]. The amount that workers send to their countries is also called migra dollars. These migrant dollars could affect the receipt countries' economies if theyuse the remittances into a productive projects. In Mexico, it is noted that 27\% of small industries depend on overseas remittances [35].

Most research in Pakistan has focused on survey data and analyzed the remittances use and affects with the help of descriptive method. In the study of Siddiqui and Kemal [29], used 1993 HIES (Households Integrated Economic Survey) data and concluded that decrease in the inflow of remittances leads to increase in poverty in Pakistan. Arif [8], analyzed remittances and investment on a household basis, the study examined that nearly 68\% workers' remittances contributed to investment and saving by the households. Alderman [5] examined five year panel data for the rural areas in Pakistan, and found that remittances were mostly invested in land and houses. Iqbal and Sattar [17] investigated that GDP level was positively affected

By the workers remittances during 1972-73 and 200203.They further considered that remittances is the third main capital source for the economic growth of Pakistan. Taylor [33] explored that migrant remittances is the main source of income in form of saving and investment. Further he found that remittances account for saving, investment, lead to economic growth and development of any economy.

Adams [2] explained that those households who receive remittances from abroad consume less compared to those who do not receive foreign remittances and also their marginal spending behavior leans more towards investment. Similarlily in the study of Emilia-Romagna, $\mathrm{R}(2007)$ pointed out about the Albanian households expenditure patterns that who receives remittances from abroad spend more on health and education, and contribute less for consumption purposes compare to those households who do not receives foreign remittances. Adams [1], used panel data for five year of rural areas in Pakistan, he found that internal remittances/domestic income used for consumptions on durable goods and nondurable goods, while external remittance are more helpful in regarding the accumulation of rural assets. In the study of Carling [12], most authors have expressed their views about the importance and impact of remittances on the 
receipt countries. Further they concluded that the long run impacts of remittances growth could be seen in form of saving and investment in the receiving countries. But in case of short run impacts on cumulative demand and output could be seen in form of consumption (cited in Thao [34]). Carling [12] has drawn the linkages between remittance and development in the following figure.

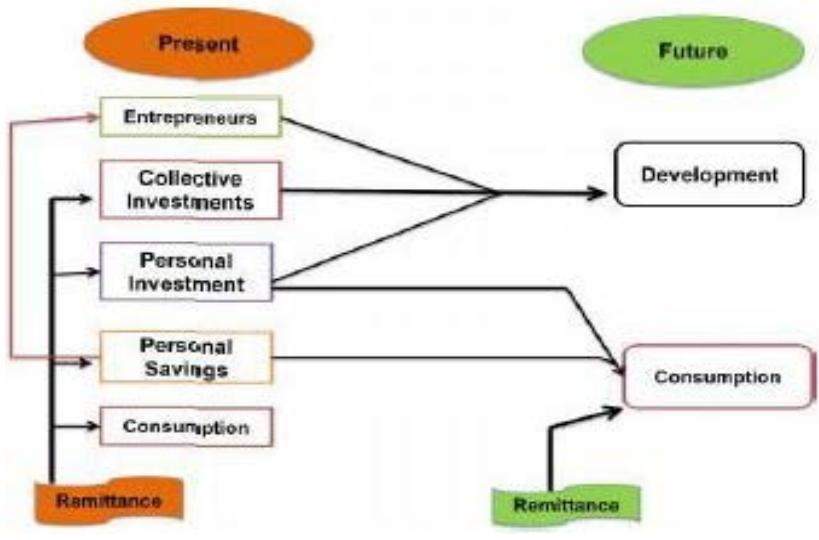

Figure 1. The linkage between remittances and development. Source: [12]

The above figure shows that remittances are using only for consumption purpose today give directions to requirement of further remittances in orderto fulfill future consumptions. If remittances are used for investment and/ or saving, it could help in futureconsumption [12].

Research on international migration in Pakistan has primarily addressed a number of concerns which can be summarized as (i) to establish the magnitude and demographic profiles of the out-migrants (ii) the returnmigrant (iii) implications of manpower experts at the macro-level and its broad aggregates (employment of labor force, GNP growth, savings, private investment) and consumption, and (iv) balance of payments [20]. Specifically, the utilization of remittances by migrants' households and by migrant on his return has been the subject of much empirical research mainly to search for incentives and policy prescriptions to channel these resources into productive uses [28].

The popular view has been that remittances largely have gone into increased consumption expenditures. But little work have been done to investigate the impact of remittances along with other socio economic variables on consumption (durable and non-durable) and investment behavior of household at micro level. Therefore this study is attempt to explore the discussion about how remittances are used or spent and their effect on the consumption and investment behavior of the household by using the field survey of Tehsil Sargodha. The results of the field survey are used to compare the marginal spending behavior of the household with other socio-economic variables (i.e. age, education, domestic income).

\subsection{Channels of Remittances Transfer}

Remittances to less developed countries occur through informal channels. An informal channel means the way of transferring where no documents are needed, such as, friends, relatives, neighbors or others travelling to the home country. Therefore it does not show in the record of a country, whereas hundi (money courier) is a tremendous popular informal transfer channel of remittance. Formal channels include banks or exchange institutes, telegraphic way, in form of traveler's cheques.in form cash and also through automatic teller machine (ATM) facilities [30]. According to Barajas et al, 2009, it has been estimated in 2007 that over US\$300 billion remittances transferred through formal channels in the world and as well as more billions transferred through informal channels.

A study by Siddiqui and Abrar [31] found that globally the flows of total remittances are transferred to households through formal channels are account to be 46 percent, whereas 40 percent is emitted through hundi followed by friends and relatives. In some cases migrant workers carry remittances by their self when they visit home.

\section{Review of Literature}

The issue of migration and remittances has been documented in the literature for the labor exporting countries. However the work done so far for Pakistan is limited in scope as compared to other labour exporting countries. It would be useful to review some of the previous studies, which could help us understand the subject in depth and help us to analyze the previous work.

Amjad [6] studied the role of remittances in investment and consumption and its impact on Pakistan's economy. Data for the analysis took from various issues of Pakistan economic survey. Furthermore the study used the results estimated by Gillani [15], according which total consumption expenditure was 62 percent, real estate 22 percent and both investment and saving also got 22 percent share in remittances. The study is a comparison of Gilani et al [15] results and concluded that the use of remittances between consumption expenditure and nonconsumption expenditure is approximately the same while consumption expenditure is slightly over than nonconsumption expenditure. The study further clarified that remittances are not wasted at all but these are used about $30 \%$ to $35 \%$ in investment.

Adams [2] explained the internal and external remittances and their impact on marginal spending behaviors of households on different kind of consumption and investment goods. The data for the study has taken through national household surveys and 7,276 households were contacted from various income groups (i.e. who receives external remittances, internal remittance and those who do not receive any kind of remittances) The study evaluated that households that receive external remittances spent 2.2 percent more on household's consumption (durable and non-durable) than those households that do not get any external remittances. This increase in the household expenditure from the individual immigrants' standpoint could be an investment with some possibilities of financial return. Adams also found that remittances have a positive effect on the receiving countries in terms of health care, education and as well as reducing poverty. To conclude, he further found that a small portion of remittances is used for savings and investments in the form of houses, property and apartments. Alderman [5] investigated saving rates in rural Pakistan. The study has selected 5 years panel data 
samples from rural Pakistan. Data contained the details about credit, sales, purchases assets and net variations in bank. The main finding of the study; remittances went to land and as well as to buildings.

Castaldo and Reilly [13] studied the impact of workers’ remittances upon the consumption patterns of Albanian households. External and Internal remittances were selected and checked for the impact on consumption patterns of households. Data for the analysis collected from the national representative Albania Living Standards Measurement Survey (ALSMS), during 2002. Data set for ALSMS was created on two-stage collection design which contained 3,599 households and 16,521 persons. The study compared different households in regarding consumptions patterns, those households who receives internal remittances, who do not receive any kind of remittances and who receive remittances from abroad. The study further found that consumption patterns of those households who receive internal remittances were not statistically different from those households who do not receive any kind of remittances.

Those households who receive remittances from abroad spent less on non- durable goods and have greater consumption on durable goods compare to those households who do not receive any kind of remittances. Further the study found that remittances from abroad brought increase of $25 \%$ in the budget of households in the consumption on durable goods and approximately $16 \%$ rise in the utilities (non-durable goods).

Griffith et al [16] investigates the role and impact of remittances in Barbados. The study has focused the housing improvements of Barbadians. For the empirical estimation Dynamic Ordinary Least Squares (DOLS) estimation method used in the study and evaluated remittances impact on investment during 1970 to 2002. The study found that remittance has a major positive impact on investment. Furthermore the study has shown that most people attracted towards investments in form of saving (bonds).

Stahl and Habib [32] explained the role of remittance in indigenous industry (i.e. livestock and other crops). Data has taken from the World Bank Survey, based on the emigration from Bangladesh. The sample of 277 households were contacted for interview (201 rural and 76 urban). The methodology used in the study was "endogenous computable general equilibrium model" which is built around a country's social accounting matrix. The found study found that small portion of remittances went to investment belongings, but it does not mean that their probable contribution towards economic development is negligible. The study gave further that remittances are used mostly in those sectors that have strong link with rest of the economy. The study also discovered if productive sector of the economy is stronger, then remittances inflow will be higher.

\section{Data and Descriptive analysis}

\subsection{Data Source and Background}

The data for this study is drawn from the field survey of the Tehsil Sargodha. According to the 1998 census total population of the Tehsil is 1.01 million. There are 52 Union Councils in this Tehsil. People are also engaged both in government and private sector services (agriculture, business, shop keeping, etc.). A large number of the population is working outside the country mostly in the Middle East, U.S.A, and Europe.

The study used a stratified random sampling technique of survey. The total area was divided into two strata, because of migrants in the area. One stratum contains of main and big towns of Tehsil Sargodha namely, Salah Khana, Dak Ismail Khel, Dag Basood and Banda Nabi while the other strata consist of other than Salah Khana, Dak Ismail Khel, Dag Basood and Banda Nabi.All other areas the number of migrants is less in towns, so this strata takes the weight of 25 percent whilst other strata represent 75 percent of the sample. The study consists of survey from those household with at least one person working outsidePakistan. During survey that those who were willing to respond on the spot were interviewed personally while those who demanded to fill the survey by themselves were given the questionnaire that was collected after one to three days. The total number of questionnaires (delivered and personally conducted) was 400 , but due to failure of some people in responding, the net sample size for the study remains 355 .

Those questionnaires were dropped from the study in which information on the key variables was missing, i.e.; remittances, personal income, expenditure etc. Similarly, those questionnaires were also dropped which consist severe contradiction in their responses, simply the answers from the household point of view was not related with the purpose of study.

Before launching the formal survey and conducting interview, pre-testing was done to ensure the best format of the questionnaire. Some questions were changed in the questionnaire to ensure correct information on key variables like remittances and domestic income and expenditures.

The basic unit of investigation is the household. A criterion for interview is that any person (irrespective of his position in home, whether household head or not) who knows about expenditure and income of the household was interviewed. As access to female members of household is difficult, because of traditional constraint, so the female folk are excluded from the survey (because of religious and cultural reason). The questions were of quantitative nature and the aim was to collect data on remittances and other key variables. The questionnaire consisted of questions on average monthly lump sum expenditure on both durable and non-durable, age, education, domestic income, migrant monthly income, religious activities, and wedding programs. It also includes question on financial investment (saving deposit) and non-financial investment (i.e. agriculture, construction, businesses, etc.) and other related economic variables.

\subsection{General Characteristic of Respondents}

Data has been collected from urban and rural area of Tehsil Sargodha. Households exhibit different economic status as from poor to lower middle and higher middle classes. The average size of the household is about 10 persons per house unit, as mostly people live jointly. In 
the sampled households behavior ranges differently, depending on different aspects. The respondents having high income (both remittances and domestic income) exhibit difference in their consumption and investment behavior. However, those respondents, who have a high education profile, show comparatively more consumption on education and traditional and social activity (i.e. weddings, funerals and ceremonies).

\subsection{Economic Profile of the Sampled Household}

The sample shows that annual average remittances is of about 0.5 million rupees (90 $\mathrm{PKR}=1$ US\$)while annual average consumption on non-durable is of about 0.3 million rupees, annual average investment is of about 0.1 million rupees and annual average consumption on durable is of about 0.025 million rupees. The range of the remittances is from 48000 to 5460000 rupees per annum around the mean. Similarly the range of consumption on non-durable is from 26,400 to 2,630,000 rupees per annum, and furthermore the range of investment is from 0 to $2,500,000$ rupees per annum and consumption on durable is from 0 to 435,000 rupees per annum.In addition to consumption and investment, small portion of remittances saved by householdsin form bonds, jewellery and property etc. Remittances also used by households in Tehsil Sargodha for debts, fares, weddings, funerals and ceremonies.

Economic status of the sampled households is reported in Table 1. The table shows the range and average data of annual remittances, domestic income, consumption (on durable and non-durable) and investment.

Generally respondents with higher remittances income show comparatively high spending on consumption and investment.

Table 2 shows this behavior of the respondent where values of yearly average consumption and investment for different income classes have been highlighted. The concentration of the table is to provide a relation of the average consumption and investment with the average remittances income. The analysis shows that value of average consumption (non-durable and durable) and investment have positive variation in most of the classes, as the value of average annual remittances change for different income classes; both average annual consumption and average annual investment also change.

Table 2 shows a positive relationship for both consumption and investment, as household moves from one income group to another income group.

\subsection{Demographic Profile of the Respondents}

Analysis of sampled respondents displays different demographic characteristic. In this regard when analyze age profile of the family, the data shows that average age of the respondent family is 23 years while the average size of the household is ten(10) members per family unit. Out of 355 households, 199 are living jointly while 156 are nuclear families. The brief account of the families has been given in the following Table 3 .

Table 1. Summary Statistics of the Sampled Households (In Rupees 000)

\begin{tabular}{|l|c|c|c|}
\hline Variable & Obs & Minimum & Maximum \\
\hline Remittances & 355 & 48 & 5460 \\
\hline Domestic Income & 355 & 0 & 6400 \\
\hline Consumption (Non-durable) & 355 & 26.4 & 2630 \\
\hline Consumption (Durable) & 355 & 0 & 304,41 \\
\hline Investment & 355 & 0 & 24,05 \\
\hline
\end{tabular}

Table 2. Relationship between Remittances and both Consumption and Investment (In Rs 000)

\begin{tabular}{|c|c|c|c|c|}
\hline Income classes (Remittances) & Arage annual Remittances & Average annual Consumption & Average annual Investment & No, of Obs \\
\hline $25 \%---35 \%$ & 418991 & 279 & 63 & 71 \\
\hline $35 \%---45 \%$ & 822812 & 452 & 97 & 71 \\
\hline $45 \%---55 \%$ & 1338.462 & 573 & 319 & 71 \\
\hline $55 \%$---65\% & 2002.857 & 898 & 486 & 71 \\
\hline $65 \%---75 \%$ & 2380.000 & 987 & 686 & 71 \\
\hline
\end{tabular}

Table 3. Demographic profile of the Sampled Households

\begin{tabular}{|l|c|c|c|}
\hline Variables & Obs & Mini & Maxi \\
\hline Family Size & 355 & 2 & 45 \\
\hline Family Size of Nuclear Family & 156 & 2 & 14 \\
\hline Family Size of Joint Family & 199 & 5 & 45 \\
\hline Family Size of Rural Area & 262 & 2 & 4.15 \\
\hline Family Size of Urban Area & 93 & 2 & 25 \\
\hline Aveg years of Education of household head & 355 & 0 & 16 \\
\hline Aveg years Age of household members & 355 & 12 & 75 \\
\hline
\end{tabular}


The above Table 3 presented the minimum and maximum number of family members in both family systems (nuclear and joint). The minimum members in nuclear family is two (2) and maximum is 14 . While in joint family system the minimum number of family member is 5 and maximum is $\mathbf{4 5}$ members. Similarly the table presented family sizes for both in urban and rural areas. The average years of education of the household head is 16, and the average age of household members is 42.All the details provided in Table 3 from the field survey in Tehsil Sargodha.

The study investigated the role of Remittances on investment, consumption (non-durable and durable goods) behavior by using statistical analysis in the following sections.

\section{Methodology}

The data have been collected from urban and rural area of Tehsil Sargodha. Households are exhibiting different economic status as from poor to lower middle and higher middle classes the average size of household is about 10 persons per house unit, as mostly people live jointly.

In chapter 3 , the sampled households behavior ranged differently, depend on their different aspects. The respondents having high income (both Remittances and domestic income) exhibits difference in their consumption and investment behavior as shown in Table 2. Similarly those respondents, who have high education profile, show comparatively more consumption on education and traditional and social activity.

Relationship of Remittances, with investment, consumption behavior and some other different variable are discussed in detail in the following section.

\subsection{Analytical techniques}

In order to examine the role of remittances on consumption (durable and non-durable) and investment in more systematic way, the following methodology has been used. The study develops a proper functional form for the model. The selected model provide a good statistical fit to a wide range of commodities (durable and non-durable) and as the main focus is on remittances consumption relationship and remittances investment relationship, the chosen form has a slope that is free to change with remittances. Therefore the log function was selected as a basic functional form.

$$
\begin{aligned}
& \log (\text { Cons })=a+b(\log D Y) \\
& \log (\text { Inv })=a+b(\log D Y)^{1}
\end{aligned}
$$

Where

"Cons" is annual consumption (durable and non-durable), and "Inv" is annual investment

"DY" is annual domestic income of the household

" $a$ " is constant and "b" is elasticity parameter

Using this function study explore the consumption expenditure and investment expenditure behavior of the household with different domestic income. As there are some various socio economic factors other than income

\footnotetext{
${ }^{1}$ We assume that the interest rate is the same for all households
}

that might affect this behavior too so are taken into account, for example differences in family size, remittances, education of household head, age of household members, family system and residence of the household etc. Thus in the abovementioned models we consider all those factors that might play a meaningful role in consumption and investment behavior of households. So the proper functional form is discussed in next section.

\subsection{Consumption and Investment Model}

On the bases of above discussion the formal equation of the model in general form is

$$
\begin{aligned}
& \mathrm{C}=\mathrm{f}(\mathrm{DY}, \mathrm{REM}, \mathrm{FAM}, \text { DFAM, DRES, EDU, AGE })(\mathrm{c}) \\
& \mathrm{I}=\mathrm{f}(\mathrm{DY}, \mathrm{REM}, \mathrm{FAM}, \text { DFAM, DRES, EDU, AGE })(\mathrm{d})
\end{aligned}
$$

Where

$\mathrm{C}=$ Annual consumption of the household

$\mathrm{I}=$ Annual Investment of the household

$\mathrm{DY}=$ Annual domestic income of the household other than Remittances

REM = Annual remittances received by the household

HS= family size of the household

DFAM= Dummy for family system (joint or nuclear)

It takes (1) for joint and is 0 other wise

DRES $=$ Dummy for residence (rural or urban)

It takes (1) for rural and is 0 other wise

EDU = Average yearsof education of household head

AGE = Average years age of household members

The parameters are estimated separately for each category of consumption and Investment.

For this analysis the basic estimation technique is ordinary least square (OLS).

\section{Results and Discussion}

\subsection{Model Specification and Estimation}

In order to highlight the importance of the remittances, we see its impact on consumption (durable and non-durables) and investment behavior of household through a careful specification of the model for the purpose of empirical analysis. As the econometric model discussed in chapter 4, carries the limitation of being general in form because we have no specification in relation of independent variables with dependent variables, so assuming it to be linear we estimate the linear function using OLS. In doing so first of all equation of consumption and investment are estimated and the behavior of expenditure pattern of household are examined. Then we make discussion on each of the independent variables and its contribution in explaining the consumption and investment behavior. In this regard we formulate the following empirical model on the base of econometric framework discussed in chapter 4.

$$
\begin{aligned}
& \log (C)=a_{0}+a_{1} \log (\text { Rem })+a_{2} \log (\text { DY })+a_{3} H s \\
& +a_{4} \text { DFAM }+a_{5} \text { DRES }+a_{6} \text { EDU }+a_{7} \text { AGE. }+€_{i} \\
& \log (I)=b_{0}+b_{1} \log (\text { Rem })+b_{2} \log (\text { DY })+b_{3} H s \\
& +b_{4} \text { DFAM }+b_{5} \text { DRES }+b_{6} \text { EDU }+b_{7} \text { AGE }+€_{i}
\end{aligned}
$$


Where $€_{i}$ is the error term.

\subsection{Estimation of Consumption Expenditure}

Model 4.1 is estimated by OLS on the basis of data on households collected from Tehsil Sargodha. The results are presented in Table 4. The estimated values of all variables in Table 4 shows that the regression coefficients of all the variables carry almost the correct expected signs. However not all the coefficients are statistically significant, however the overall model is significant.

Table 4. Estimation of Empirical Model for consumption

\begin{tabular}{|c|l|c|c|}
\hline Variables & \multicolumn{1}{|c|}{ Explanation } & Coefficient & t-Statistic \\
\hline Constant & Intercept & 7.72 & $18.79^{*}$ \\
\hline $\log ($ REM) & Annual remittances in rupees & 0.021 & $7.00^{*}$ \\
\hline $\log (\mathrm{DY})$ & $\begin{array}{l}\text { Annual domestic income in } \\
\text { rupees }\end{array}$ & 0.09 & $4.65^{*}$ \\
\hline HS & Household size & 0.06 & $9.11^{*}$ \\
\hline EDU & $\begin{array}{l}\text { Average years education of } \\
\text { household }\end{array}$ & 0.03 & $3.66^{*}$ \\
\hline AGE & $\begin{array}{l}\text { Average years age of } \\
\text { household members }\end{array}$ & 0.01 & $3.09^{*}$ \\
\hline DFAM & $\begin{array}{l}\text { Family system=1 if joint, } \\
\text { other wise, } 0\end{array}$ & -0.12 & $-2.05^{*}$ \\
\hline DRES & Residence=1 if rural=0 & -0.06 & -1.12 \\
\hline
\end{tabular}

Note $=*$ show significance at $5 \%$ level

$\begin{array}{lll} & \text { R-squared } & 0.518561 \\ \text { Adjusted } & \text { R-squared } & 0.506940 .\end{array}$

It is clear from the above results in Table 4 that the most important factors affecting the consumption expenditure behavior are remittances, domestic income, family system, education, average age and household size. However, the variable of residence dummy (DRES) is insignificant in influencing the consumption expenditure behavior.

\subsubsection{Interpretation of Results}

The clear observation is that the estimated value of intercept is showing highly significant at standard level of significance. In addition, the variables have expected signs. The value of $\mathrm{R}$ square is sensibly good for cross sectional analysis.

The coefficient of remittances, $\square_{1}$, is showing 0.021 in the above table and significant at 5 percent level. Table 4 shows that, the explanatory variable (REM) is the main economic factor that influences consumption behavior. For the model 5.1, $\square_{1}=0.021$. We would conclude that one percentage change in remittances results 2.1 percent change in consumption of the household. The result is compatible with the empirical analysis of other researchers like; Castaldo and Reilly (2007) (1986), they concluded that those households who receive remittances from abroad spent less on non-durable goods and consume more durable goods compare to other households. Similarlily domestic income (DY), its coefficient is positive and significant. The annual domestic income in model 5.1, $\square_{2}=0.09$. The result shows that one percent change in domestic income leads to 9 percent change in consumption. As the income elasticity is less than one, only $0.09 \%$ internal income use for consumption purposes.
The result tells that who has additional domestic income with external remittances can saves and invest more compare to other households.

It is clearly showing from Table 4 that demographic factors like household size (HS) do share an important factor in influencing consumption behavior, its coefficient shows positive and significant. It indicates that consumption is positively related with the increase of family size, because it increases the consumption of the household.

The coefficient of education (EDU) in Table 4 explains positive and significant effect on consumption. This may be due to the reason that as average level of education of household members increases then education expenditure also increases, as a result consumption increase.

The coefficient of household members' average age (AGE) in Table 4 shows positive and significant effect on the consumption. The reason of its positivity could be the fact that as household family gets older their expected life decrease and to get maximum utility of their available resources they will try to assign more for consumption. Another reason could be that when average age of the household unit increase, their possible consumption might be increase demanding more resources for its fulfillment.

The coefficient of family system (DFAM) in Table 4 shows negative and insignificant relation with consumption. The negative sign of the family system shows that those who live in joint family system consume less as compare to nuclear family. The result clearly shows that those who are living in joint family system enjoy economies of scale, means that lower average costs compare to nuclear family.

Similarlily the coefficient of residences (DRES) shows negative and insignificant impact on consumptions of the household. The negative sign indicates that those who are living in rural areas consume less as compare to those who lives in urban areas. As the cost of living is comparatively high in urban areas therefore consumption might be more, however this result is insignificant.

\subsection{Estimation of Investment Expenditure}

Similarly Equation 4.2 is estimated by OLS with the given data from Tehsil Sargodha. The results are presented in Table 5, which indicates that the regression coefficient of all variables carry almost the correct expected signs. However, all the coefficient are not statistically significant, but overall model is significant.

Table 5. Estimation of Empirical Model for Investment

\begin{tabular}{|c|l|c|c|}
\hline Variables & \multicolumn{1}{|c|}{ Explanation } & Coefficient & t-Statistic \\
\hline Constant & Intercept & 4.17 & $2.93^{*}$ \\
\hline Log(REM) & Annual remittances in rupees & 0.021 & $2.06^{*}$ \\
\hline Log(DY) & $\begin{array}{l}\text { Annual domestic income in } \\
\text { rupees }\end{array}$ & 0.37 & $5.23^{*}$ \\
\hline HS & Household size & 0.03 & 1.31 \\
\hline EDU & $\begin{array}{l}\text { Average years education of } \\
\text { household }\end{array}$ & -0.04 & -1.13 \\
\hline AGE & $\begin{array}{l}\text { Average years age of } \\
\text { household members }\end{array}$ & 0.003 & 0.23 \\
\hline DFAM & $\begin{array}{l}\text { Family system=1 if joint, } \\
\text { other wise, 0 }\end{array}$ & -0.46 & $-2.14^{*}$ \\
\hline DRES & Residence=1 if rural=0 & -0.29 & -1.41 \\
\hline
\end{tabular}

Note $=*$ show significance at $5 \%$ level

R-squared 0.174821

Adjusted $\quad$ R-squared $\quad 0.15085$ 
As it is clear from the results that most important factors affecting the investment expenditure behavior are remittances, domestic income and as well as family system.

Before interpretation of different parameters, there are some variables are in significant in the influencing the investment expenditure behavior, such as, average age of the household members (AGE) and residence (DRES) and since the existence of highly insignificant parameters in regression equation generally erodes the superiority of other parameters. Therefore the average age (AGE) variable is dropped from regression equation before going to interpreting the other parameters.

\subsubsection{Interpretation of Results}

The calculated coefficient of intercept is significant, so this result indicates that there are other factors not involved in the study that could have effect on investment expenditure behavior. Table 6 shows that explanatory variable remittances (REM) is an important that influences investment expenditure behavior. Remittances elasticity of investment is lower than one and show significant, which well-matched to the empirical analysis of Castaldo and Reilly [13]. For the model 5.2, $\square_{1=0.021}$. It means that one percent change in remittances 2.1 percent change in investment. The domestic income (DY) is also one of the vital factors that affect this investment behavior. The result shows that when domestic income of the household increase investment also increases and its coefficient is significant. In equation

5.2, $\square_{2}=0.37$. We would conclude that one percent change in domestic income so it's mean that $38 \%$ change in investment. This additional amount from the domestic income are more helpful in investment purpose, for those households who are receiving remittances from abroad and they invest more compare to others (who are not receiving remittances from abroad).

Table 6. Estimation of Empirical Model for Investment (After dropping variable AGE)

\begin{tabular}{|c|l|c|c|}
\hline Variables & \multicolumn{1}{|c|}{ Explanation } & Coefficient & t-Statistic \\
\hline Constant & Intercept & 4.21 & $3.00^{*}$ \\
\hline Log(REM) & $\begin{array}{l}\text { Annual remittances in } \\
\text { rupees }\end{array}$ & 0.021 & $2.07^{*}$ \\
\hline Log(DY) & $\begin{array}{l}\text { Annual domestic income } \\
\text { in rupees }\end{array}$ & 0.37 & $5.36^{*}$ \\
\hline HS & Household size & 0.02 & 1.29 \\
\hline EDU & $\begin{array}{l}\text { Average years education } \\
\text { of household }\end{array}$ & -0.03 & -1.10 \\
\hline DRES & $\begin{array}{l}\text { Family system=1 if joint, } \\
\text { other wise, 0 }\end{array}$ & -0.29 & -1.40 \\
\hline DFAM & Residence=1 if rural=0 & -0.46 & $-2.13^{*}$ \\
\hline
\end{tabular}

Note $=*$ show significance at $5 \%$ level

$\begin{array}{lll} & \text { R-squared } & 0.174637 \\ \text { Adjusted } & \text { R-squared } & 0.154173 .\end{array}$

Furthermore, it is obvious from the Table 6 that demographic factors like household family size (HS) do share in influencing investment expenditure behavior positively but its results show insignificant in the estimation.

Likewise the coefficient of education of the household head (EDU) in Table 6 illustrates negative and show insignificant effect on investment.

Similarlily the coefficient of residence (DRES) in Table 6 shows negative relationship with investment. This means that those who are living in rural areas invest less compare to those who are living in urban areas. However, this result is insignificant.

Table 6 indicates that the coefficient of family system (DFAM) shows negatively and insignificant impact on the investment behavior. The negatives sign declares that those who are living in joint family system invest less compare to nuclear family. This result is contradictory with result in estimated for the consumption equation. One reason might be that in joint family system one enjoy economies of scale in consumption but in absolute term their consumption are high so leaving less for investment purpose while in nuclear family no such problem exist. Another possible reason could be under reporting about investment by the joint family household respondent. As there commonly remain asymmetry in information about ones revenues and its exact uses in different ways.

\section{Conclusion}

The study investigated the impact of remittances with other socio economic variables on consumption and investment, one year data (1st January, 2011-31 December, 2011) collected from the field survey of Tehsil Sargodha. The study has analyzed sample of 355 households, who have at least one person working abroad. The data is regressed by OLS method and found the following results.

The study found a positive association between consumption behavior and remittances. Similarly a positive relationship has been found with domestic income and a dummy used for the family system where the result is that those who are living in nuclear family system bear more burdens in terms of consumption. The result is indicative of the fact that if one is interested in saving more and planning to achieve some monetary objectives then he has to sacrifice living in nuclear family. The study investigated that household receives of external remittances and domestic income use $2.1 \%$ and $9 \%$ respectively, for consumption purposes, which shows contradiction with some of the earlier studies, like findings of Lipton [22], which shows that more than $90 \%$ remittances are used for consumption purposes. Similarly the study also derives a positive association between investment behavior and remittances as well as a positive relation of investment with domestic income.

The study have derived that remittance and domestic income both play positive role in determining the behavior of the people regarding consumption and investment. As the people are positive towards investment, so if additional employment oriented avenues of investment are provided then a far better and optimal utilization of these resource will be made possible.

From the survey date it is clear that households are also used remittances for social purposes like wedding, funerals and ceremonies. This is particularly true because of our cultural setups that wedding has to be expensive because of parties, clothes, dishes and guests. Similarly funerals are also costly because of religious point of view. Migrants support their families in wedding, funerals and ceremonies because they consider it is also investment and hence they will expect similar help in future. 
In Pakistan, helpful policies are required to encourage the use of remittances to support longterm development and income security. Policies can be successful in encouraging migrants to channel remittances through official channels than unofficial channels and will also help them to keep their savings in form financial assets than keeping abroad.

\section{References}

[1] Adams, Jr., R. (1998). Remittances, investment, and rural Assets Accumulation in Pakistan. Economic Development and Cultural change, 47(1), pp. 155-173.

[2] Adams, Jr., R. (2005). Remittances household expenditure and investment in Guatemala. World Bank, Policy research working paper, 3532.

[3] Adams, Jr., R. (1989). Workers' Remittances and Inequality in Rural Egypt. Economic Development and cultural change, 38(1), pp. 45-71.

[4] Adams, Jr., Cuecuecha., \& Page. (2008). Remittances, Consumption and Investment in Ghana. Policy Research Working Paper 4515. The World Bank Development Economics Department \& Africa Region.

[5] Alderman, H. (1996). Saving and Economic Shocks in Rural Pakistan. Journal of Development Economics, 51.pp. 343-365.

[6] Amjad, R., \& Ahmed, M. (1986). Impact of Workers’ Remittances from the Middle East on Pakistan's Economy: Some Selected Issues. The Pakistan Development Review, 25(4), 757-782.

[7] Amjad, R. (2006). Remittances and Development in South Asia. South Asian Journal, Vol. 6.

[8] Arif, G.M. (1999). Remittances and Investment at the Household Level in Pakistan. Pakistan Institute of Development Economics. Research Report No. 166.

[9] Arif, G.M. (2004). Effects of overseas migration on household consumption, education, health and labour supply in Pakistan. Institute of Developing Economics ASEDP, no; 70

[10] Barajas, A., Chami, R., Fullenkamp, C., Gapen, M., \& Montiel, P. (2009). Do Workers' Remittances Promote Economic Growth? IMF Working Paper.

[11] Brown, R.P.C. (1994). Migrants’ remittances, savings and investment in the South Pacific. International Labour Review, 133 (3), 1-19.

[12] Carling, J. (2004). Policy options for increasing the benefits of remittances. Working Paper No.8, Centre on Migration, Policy and Society. University of Oxford, Oxford

[13] Castaldo, A., \& Reilly. (2007). Do Migrant Remittances Affect the Consumption Patterns of Albanian Households? Southern-Eastern Europe Journal of Economics 1, pp. 25-54.

[14] Emilia-Romagna, R. (2007). Migration, Remittances and their impact on human development in Albania. A study on the variations of households patterns of expenditures at the receipt of remittances: focus on health and education. Work Package 4, Activity 4.3. Bologna (Italy) European Investment Bank/Facility for Euro-Mediterranean Investment and Partnership (2006), Study on improving the efficiency of workers remittances in Mediterranean countries.

[15] Gilani, I., Khan, M., \& Iqbal, M. (1981). Labour Migration from Pakistan to the Middle East and Its Impact on the Domestic Economy Part1. Pakistan Institute of Development Economics, Islamabad, (Research Report Series 126).

[16] Griffith, R., Boucher, T., McCaskie, P., \& Craigwell, R. (2008). Remittances and Their Effect on the Level of Investment in Barbados.
[17] Iqbal, Z., \& Sattar, A. (2005). The Contribution of Workers' Remittances to Economic Growth in Pakistan. Research Report. Pakistan Institute of Development Economics Research Report 187.

[18] Javaid, W. (2016). Impact of Foreign Direct Investment On Economic Growth of Pakistan-An ARDL-ECM Approach (Dissertation). Retrieved from http://sh.divaportal.org/smash/get/diva2:944306/FULLTEXT01.pdf.

[19] Javaid, W. (2017). Impact of Foreign Financial Inflow on Economic Growth of Pakistan. Do Remittances, Foreign Aid, and ODA Behave Similarly?. Journal of Behavioural Economics, Finance, Entrepreneurship, Accounting and Transport, 5(1), 10-18.

[20] Kandil, M., \& Metwally, M.F. (1990). The Impact of Migrants' Remittances on the Egyptian Economy. International Migration, 28(2), 159-180

[21] Ledesma, M., \&Piracha, M. (2004). International migration and role of remittances in Eastern Europe. International migration, 42(4), 65-83.

[22] Lipton, M. (1980). Migration from the rural areas of poor countries: The impact on rural productivity and income distribution. World Development, 8(1), 1-24.

[23] Maimbo, S.M., \&Ratha, D. (2005). Remittances development impact and future prospects, World Bank publications.

[24] Malik, J. S., and Sarwar, N. (1993). Some test for differences in consumption patterns: the impact of remittances using household income and expenditure survey data of Pakistan. The Pakistan development review, 32(4) part 11, 699-711

[25] Nasir, M., Tariq, M.S., and Rehman, F. (2011). The Effect of Foreign Remittances on Schooling: Evidence from Pakistan, Pakistan Institute of Development Economics (PIDE) Working Paper.

[26] Nishat, M., \& Bilgrami, N. (1991). The Impact of Migrant Workers Remittances on Pakistan Economy. Pakistan Economic and Social Review, No. 1, 2141. Link: http://www.jstor.org/stable/25825057.

[27] Ratha, D., \& Shaw, W. (2005). Global economic pr0spects 2006: economic implications of remittances and migration, World Bank Publication.

[28] Shah, J. (1995).Impact of International Migration on Consumption, Investment, and Informal Financial Sector

[29] Siddiqui, R., \& Kemal, A.R. (2002). Remittances, Trade Liberalization and Poverty in Pakistan: The Role of Excluded Variable in poverty Change Analysis. A PIDE Research Study under the project of globalization and poverty in south Asia.

[30] Siddiqui, T., (2004). Efficiency of Migrant Workers’ Remittance: The Bangladesh Case. Dhaka: ADB (Asian Development Bank) and RMMRU (Refugee and Migratory Movements Research Unit)

[31] Siddiqui, T., \& Abrar, R.C. (2003). Migrant Worker Remittances and Micro-Finance in Bangladesh. Dhaka: ILO (International Labour Organization) and, RMMRU (Refugee and Migratory Movements Research Unit).

[32] Stahl, W.C., \&Habib, A. (1989). The impact of overseas workers remittances on indigenous industries: Evidence from Bangladesh. The Developing Economies, vol. 27 (3), 269-285.

[33] Taylor, J.E., Arango, J., Hugo, G., Kouaouci, A., Massey, S.D \& Pellegrino, A. (1996). International Migration and National Development. Population Index,62(2), 181-212.

[34] Thao, N.M., (2009). Migrattion, remittances and economic development: Case of Vietnam. Available at: <http://www.trf.or.th/TRFGallery/Upload/Gallery/Documents/File s/1000000027.pdf $>$.

[35] Woodruff, C., \& Pentene, R. (2001). Remittances and microenterprises in Mexico. Working paper UCSD. 